\title{
Parabolic trough solar collectors
}

\author{
TVR Sekhar, Gopal Nandan, Ravi Prakash*
}

\begin{abstract}
Solar collector in the shape of a parabolic mirror reflects the incident solar energy on the longitudinal axis of the solar collector. This line is called the focal axis of the parabolic collector. Unlike in flat plate collectors which have absorbent coatings and where the solar radiation is absorbed and distributed uniformly in the flat plate area, parabolic collectors concentrate the radiation in the focal axis of the collector. This major difference in the geometrical feature of the parabolic collectors helps in a large way. This feature enables the parabolic collectors to achieve high outlet temperatures of the working fluids, sometimes $120^{\circ} \mathrm{C}$ or as high as $140^{\circ} \mathrm{C}$. This feature allows the parabolic concentrators to be integrated with solar thermal systems. The present work intends to review contemporary research work undertaken on parabolic trough type solar collectors. The present study has classified various investigations on the basis of collection of the data like direct experimentation as well as numeration methods and by using simulation methods on collectors and it is inferred that there is a potential for experimenting with nano-fluids in parabolic trough solar collectors and validating the obtained data with simulation results.
\end{abstract}

\section{KEYWORDS}

Parabolic Trough, Simulation, Solar Collector, optical efficiency, thermal efficiency

\section{INTRODUCTION}

Harnessing solar energy has been a constant endeavor of mankind since the development of mankind. However, with the development of the concept of photovoltaic cells, commercial development of solar energy for electrical power production and community energy distribution has commenced. But today the scenario requires a greater contribution from the renewable energy sector than ever before and more so from the solar energy sources.

Amity University, Sector-125, Noida 201313, Uttar Pradesh, India

*Corresponding author; email: rprakash@amity.edu
This demand comes with a condition of cleaner solar energy than yesterday. We know that poly crystalline cells used in solar PV have inherent problems. Battery banks are required for such PV panels wherein the converted electrical energy is stored. The polycrystalline cells are manufactured using a refined form of silica which is obtained by mining huge deposits of natural riverside sands. Again, this is a source of air and river pollution. Considering these drawbacks of PV technology solar thermal concentrating technology offers energy conversion at a much-reduced footprint of pollution, after the completion of their useful life periods. It is imminent that a rapid transition to solar thermal based technologies on a large scale integrated energy conversion system takes place replacing the presently practiced small and medium scaled application of solar PV technology.

\section{Basic Features of Parabolic Solar Collectors}

The parabolic solar collector consists of the main three components, the parabolic solar reflector, a mounting stand and the receiver engine or the absorber pipe. The parabolic reflector could be a dish type construction or a trough type construction. In case of a parabolic dish the entire incident solar radiation is concentrated at a focal point and it is collected by a receiver device called the engine. This highly concentrated energy is converted into thermal energy by this engine for further storage in thermal devices. In the case of a parabolic trough, the insolation is reflected from the reflector surface and concentrated in a linear axis of the parabolic receiver. The heat absorbing tube containing the working fluid is mounted in this axis and picks up the heat from the heated tube and thus converts into thermal energy of the working fluid. The same is either stored in thermal storage tanks or used to heat other fluid in heat exchangers.

\section{Parabolic Solar Collectors}

Parabolic solar collectors are classified as Parabolic Dish type or Parabolic Trough type collectors. Classification is based on the geometry of the receiver i.e. dish or trough. 
The parabolic trough collectors are further classified as tracking and non- tracking type collectors depending on the applications and the desired outlet temperature parameters of the output fluid. The non-tracking types are fixed type collectors. The tracking collectors are again classified into single-axis tracking and two-axis tracking.

\section{Parabolic Dish Solar Collectors}

A Sterling engine based parabolic type collector is seen in Fig.1.The focused rays are concentrated at a small area. The receiver shown in Fig. 1 is usually made of a sheet of high thermal conductivity metal, (copper or aluminum) with integrated tubes. A highly absorbent material is coated to improve the absorptivity and reduce the reflectivity.

\section{Parabolic Trough Solar Collectors}

The two types of parabolic collectors are Simple Parabolic collector and compound parabolic collector. The simple parabolic collector consists of a single parabolic reflective surface. The compound parabolic concentrator consists of two parabolic reflective surfaces and the superimposed focal axis of both the parabolic surfaces receives radiation of much higher intensity when compared with a simple parabolic collector.

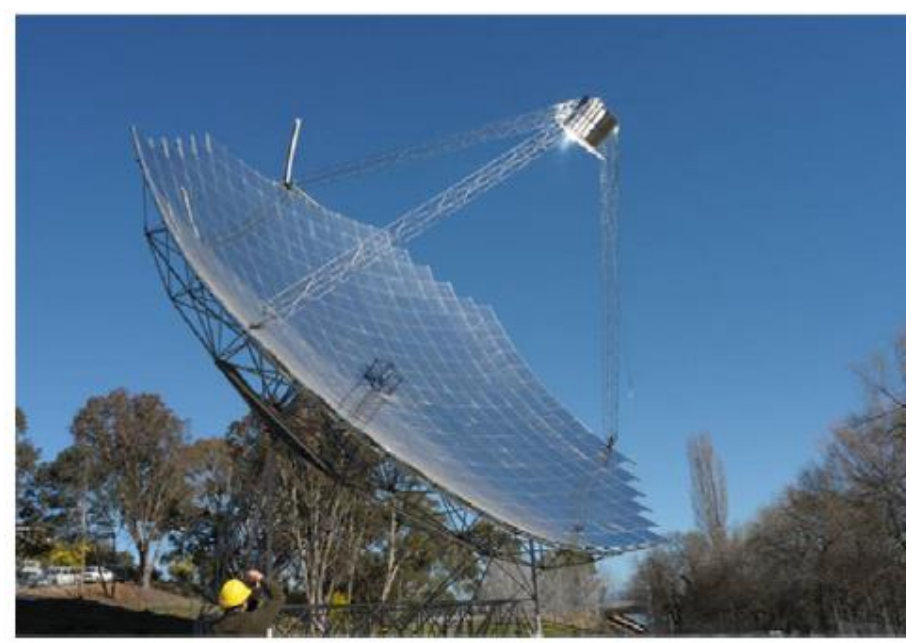

Fig.1 Parabolic Dish Type solar collector

\section{Objective of the overview}

In the present work, overview of parabolic solar collectors has been segmented into three parts. First part focuses on the experimental studies, second part highlights the numerical studies and third part focuses on the simulation studies available in literature. Application of simulation study provides detail insights into the performance and geometrical aspects of the parabolic trough solar collector. The future scope of work seeks to benefit researchers employing experimental methods for the testing of the parabolic trough solar collectors for validating their results with the numerical and simulation techniques and widening the applications of parabolic trough collectors for newer applications.

\section{EXPERIMENTAL STUDIES ON PARABOLIC SOLAR}

Bellos et al. conducted experimental investigation on a trough collector comprising of a $70 \mathrm{~mm}$ diameter receiver tube with water as the working fluid. For this set up, at different mass flow rates, thermal performance is calculated. Optimum thermal performance was recorded at a flow of $2 \mathrm{~kg} / \mathrm{s}$ in this study. Wang et al. attempted to enhance the optical efficiency of a parabolic trough collector. In order to achieve a high efficiency, heat exchanger with synthetic oil and water as the fluids were used in the absorber section of the collector. Higher order optical efficiencies of around $77 \%$ were recorded in the experimental study. Kordmahaleh et al. integrated thermal storage tanks to capture extra solar heat for use at night times. By this integration, total operating time of the plant increased from $1726 \mathrm{hrs}$ to $2785 \mathrm{hrs}$. Kasaeian et al. experimented with a steel mirrored reflector surface collector of $1.5 \mathrm{~m}^{2}$. They used painted tube surface of absorber and compared their optical and thermal efficiency according to ASHRAE standard 93 (2010). The thermal efficiency increased in vacuumed absorber tube in compare to exposed absorber tube. Khullar et al. used nanofluid in receiver and found that thermal efficiencies increased $4 \%$ from conventional collector.

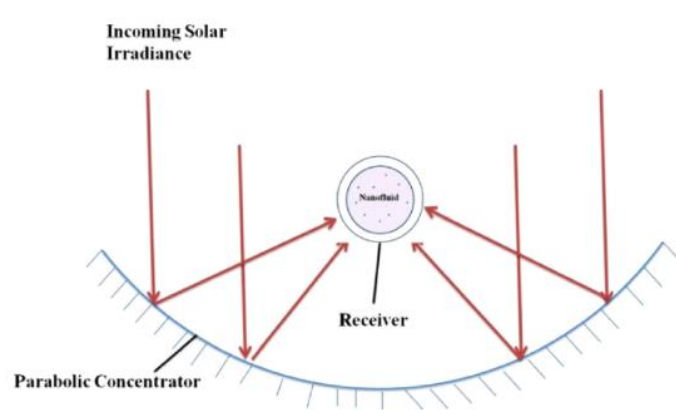

Fig. 2 Nanofluid as cooling fluid in Parabolic Solar Collector (Khullar et al. 2012) 
Sokhansefat et al. made valuable experimental contributions by understanding the direct dependency of convective heat transfer coefficient on the volume concentrations of the alumina nano-particles when used as a working fluid in a parabolic trough collector. Heat flux distributions are shown in Fig. 3 and Fig.4. It is clearly evident that flux concentration zone is in the bottom of the absorber tube and the temperature distribution follows a like pattern.
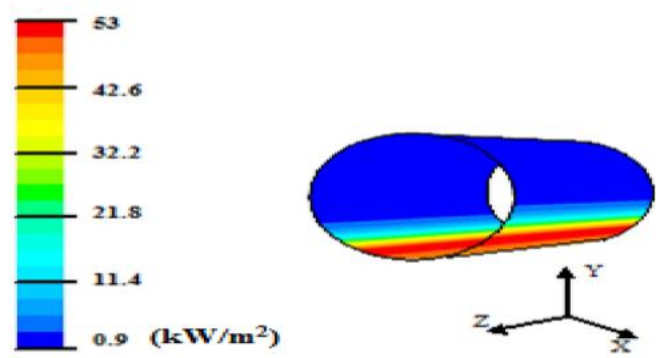

Fig. 3 Heat flux distributions on the outer surface of the absorber tube (Sokhansefat et al. 2014)
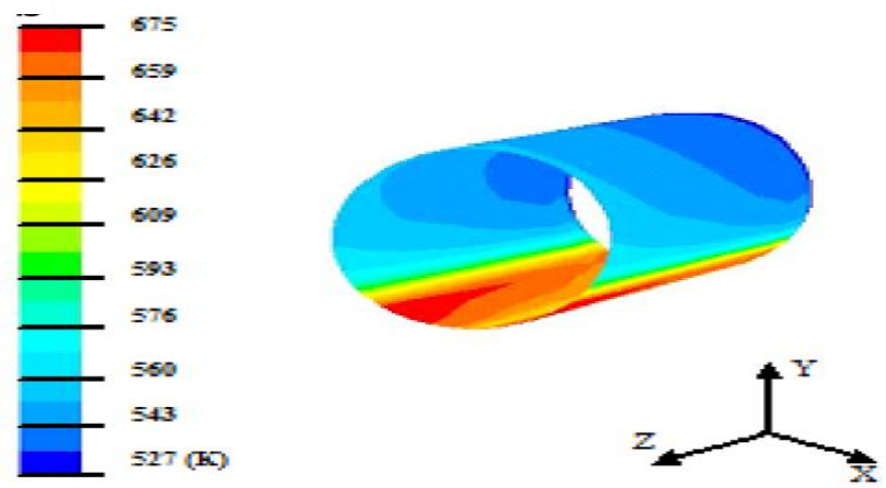

Fig. 4 Temperature distributions on the outer surface of the absorber tube (Sokhansefat et al. 2014)

Eames et al. introduced baffles into the parabolic collector cavity and studied the improvements in thermal and optical efficiency. Valenzuela et al. conducted sensitivity analysis on a parabolic trough collector in industrial scale and studied the effect of temperature, pressure and direct normal irradiance on the pressure losses at higher ranges of operation. Tayade et al. used Aluminum sheet in the shape of a parabolic cylinder to reflect and concentrate sun radiations radiation towards an absorber tube. Fernandez et al. employed Titanium oxide nanoparticles to study the catalytic behavior of the sunlight on the organic contamination agents in the aquatic environment. They proved that it is an economical option.

Kalogirou et al. conducted investigations on parabolic (PTC), compound-parabolic (CPC) and Fresnel prism (FPC) collectors and it was deduced from the analysis that the parabolic trough collector based desalinating plant was the economical option best suited as per Fig.5.

Abu-Hamdeh et al. experimentally demonstrated an olive waste and methanol based adsorbent refrigeration system which runs on solar heating source such as a parabolic trough solar collector. The coefficient of performance that was obtained was around 0.75 for the device studied. Several researchers have conducted experiment in the African country of Algeria to estimate the harnessing potential of solar radiation with the help of parabolic trough collectors (Ouagued et al.). Different heat transfer fluids were tested in different climatic regions of Algeria with the help of tracking type collectors. Calisea et al. used a triangular shaped receiver test section as shown in Fig.6. Exergetic analysis for the set up as well as sensitivity analysis for the experimental set up was carried out.

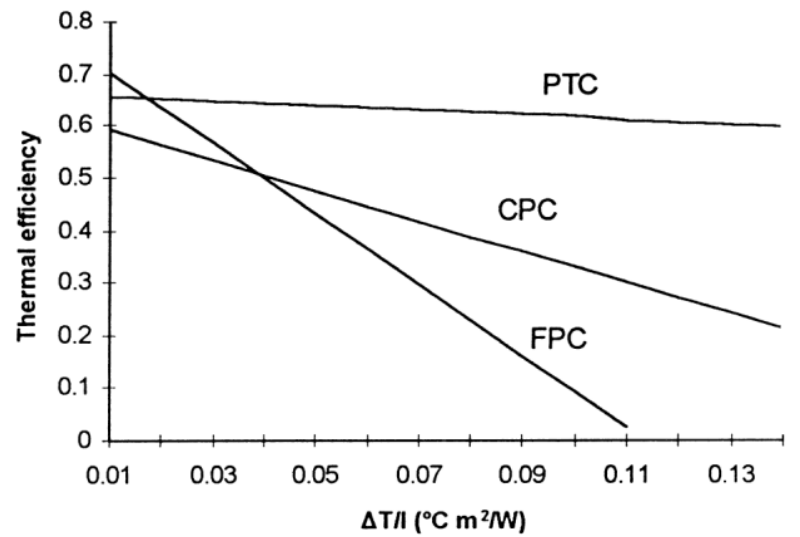

Fig. 5 Comparison of the efficiencies of Parabolic, CPC \& Fresnel Prism Collectors (FPC) (Ouagued et al. 2013) 


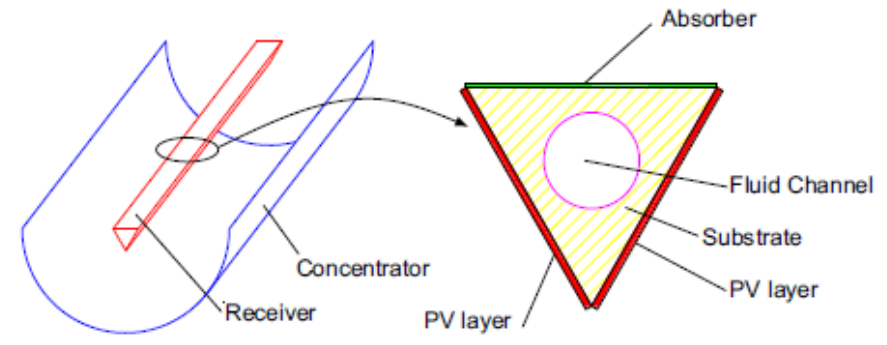

Fig. 6 A triangular absorber tube placed in a parabolic collector (Calisea et al. 2012)

Nalwangaa et al. performed an interesting experiment of disinfecting bacterial infested samples by placing them in a transparent absorber tube in the focal axis of a parabolic trough collector as seen in Fig.7. The study was conducted across the regions of the sub-Saharan desert regions of Africa.

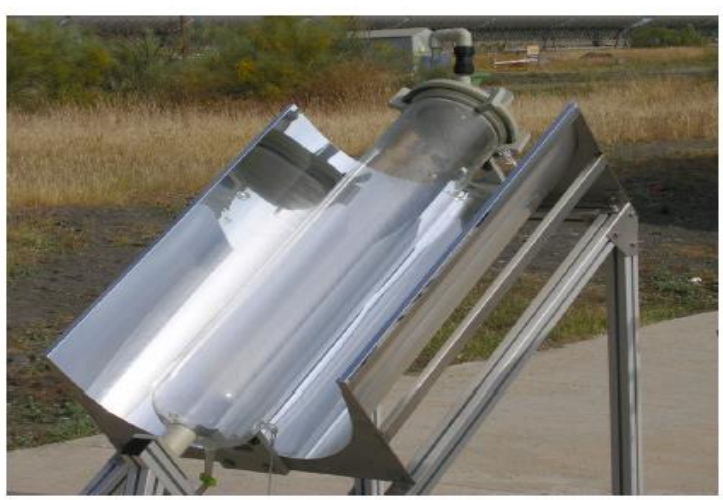

Fig.7 A compound parabolic collector with borosilicate glass absorber tube (Nalwanga et al. 2014)

Pecha et al. conducted experiments to determine the instantaneous efficiency of the collector as per ASHRAE guidelines. Optical efficiency was also determined. Chaudhary et al. studied a solar cooker with a thermal storage device like the phase change material. The study compared the efficiencies of the solar cooker coated with black paint and glazed surfaces in relation to conventional solar cookers with thermal storage arrangements. The experimental studies are tabulated as below.

\section{NUMERICAL STUDIES ON PARABOLIC SOLAR COLLECTORS}

Various researchers reported numerical studies. Hachicha et al. conducted numerical study on a Parabolic trough collector based on FVM (Finite Volume method) to predict the performance of the collector. The study determined the solar flux distribution around the absorber tube with relatively high accuracies. Ghasemi et al. numerically investigated on the performance of the $\mathrm{CuO}$ water nano-fluid and reported the effect of volume fractions, absorber tube dimensions. It was deduced that Volume fraction of nano-particles plays a significant role in the improvement of the thermal efficiency of the collector. Figs 8 and 9 show the numerical investigation results of the study.

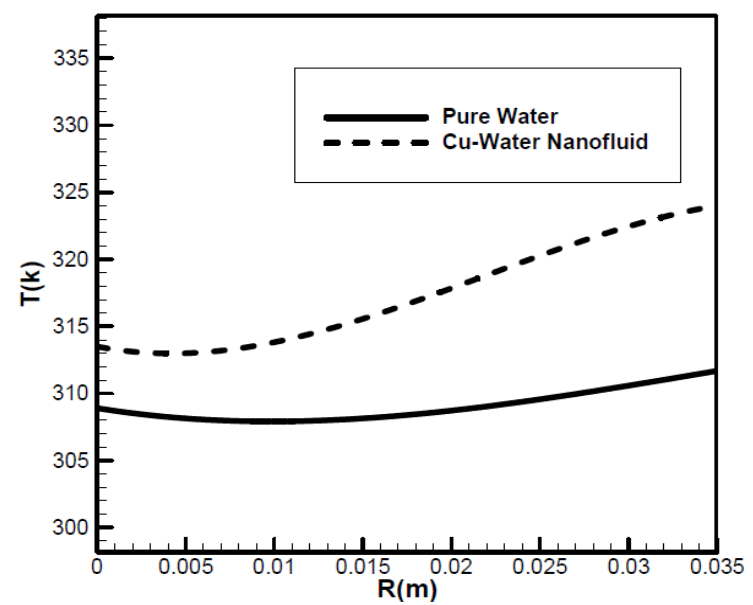

Fig. 8 Two Dimensional temperature fields for water and Copper water nanofluid (Ghasemi et al. 2014)

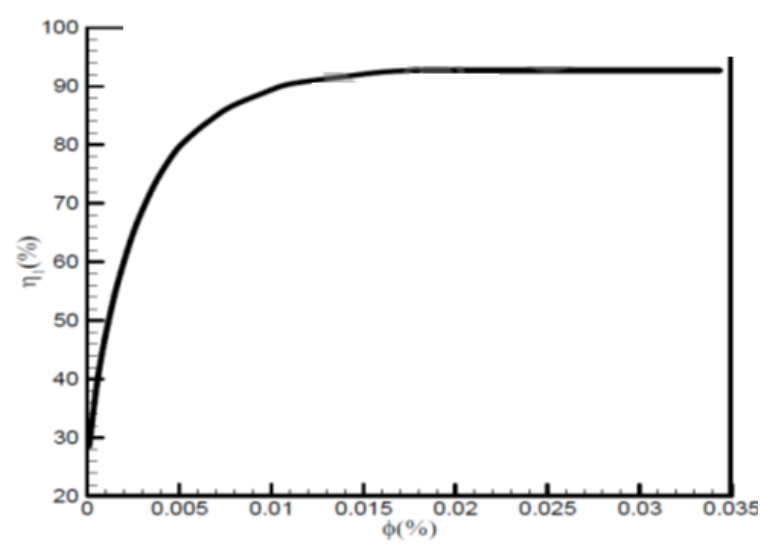

Fig.9 Thermal efficiency vs Volume fractions of copper oxide nanofluid (Ghasemi et al. 2014)

Khullar et al. compared the heat absorbing capacities of different nano-fluids by subjecting them to a direct absorption based linear parabolic trough collector. Different aspects like absorber tube radius are studied in relation to the solar irradiance absorbing capacity of the 
subjected nano-fluids. The results of the numerical investigations are shown in Fig.10. Montes et al. numerically investigated on an integrated Solar Combined Cycle (ISCC) power plant. This plant consists of a direct steam generating parabolic trough collector (PTC) with a combined cycle gas turbine-based power

\begin{tabular}{|c|c|c|}
\hline Investigators reference & Fluid used in collector & Efficiency Study Conducted \& Reasons \\
\hline Bellos et al. & Water & $\begin{array}{l}\text { At Lower flow rates lower thermal efficiencies of } \\
\text { collector were obtained. }\end{array}$ \\
\hline Wang et al. & Water/synthetic oil & $\begin{array}{l}\text { Using heat exchanger in absorber section led to high } \\
\text { optical efficiency of collector. }\end{array}$ \\
\hline Kordmahaleh et al. & Water & $\begin{array}{l}\text { Integration with thermal storage tanks increased total } \\
\text { operating time of plant by } 61 \% \text {. }\end{array}$ \\
\hline Kasaeiana et al. & water & thermal efficiency is higher in vacuumed absorber \\
\hline Khullar et al. & $\begin{array}{l}\text { Aluminum oxide nano-fluid } \\
\text { with Therminol VP }\end{array}$ & $5-10 \%$ increase in collector efficiency \\
\hline Sokhansefat et al & Water/alumina nanofluid & $\begin{array}{l}\text { Heat flux concentration zones were developed at } \\
\text { bottom of receiver tube. }\end{array}$ \\
\hline Eames et al. & Water & $\begin{array}{l}\text { thermal and optical efficiency improved due to baffles } \\
\text { in collector }\end{array}$ \\
\hline Valenzeula et al & water & $\begin{array}{l}\text { Sensitivity analysis of collector was conducted using } \\
\text { parameters like temperature, pressure and solar } \\
\text { insolation on collector efficiency. }\end{array}$ \\
\hline Tayade et al. & Water & Low cost parabolic trough \\
\hline Fernandezet al. & $\begin{array}{l}\text { Titanium-oxide nano- } \\
\text { particles }\end{array}$ & Higher efficiency is achieved using nanoparticles \\
\hline SoterisKalogirou et al. & Saline water & $\begin{array}{l}\text { Efficiency of collector using PTC increased desalined } \\
\text { water output }\end{array}$ \\
\hline Abu-Hamdeh et al. & $\begin{array}{l}\text { Olive waste as adsorbent and } \\
\text { methanol as adsorbate }\end{array}$ & $\begin{array}{l}\text { Collector efficiency improved refrigeration } \\
\text { performance. }\end{array}$ \\
\hline Ouagueda et al. & $\begin{array}{l}\text { Syltherm 800, Therminol D12, } \\
\text { Santotherm LT, } \\
\text { Marlotherm X }\end{array}$ & $\begin{array}{l}\text { Higher outlet temperature increased efficiency of } \\
\text { collector. }\end{array}$ \\
\hline Jie Zhu et al. & water & $\begin{array}{l}\text { Installation area reduction led to higher efficiency per } \\
\text { unit area of the collector. }\end{array}$ \\
\hline Calisea et al. & water & $\begin{array}{l}\text { Exergetic efficiency is calculated for comparison with } \\
\text { circular shaped collector. }\end{array}$ \\
\hline Nalawanga et al. & Bacteria Infested water & $\begin{array}{l}\text { Efficiency of disinfection of bacteria using concentrated } \\
\text { solar radiation was improved }\end{array}$ \\
\hline Pecha et al. & water & $\begin{array}{l}\text { Instantaneous efficiency of collector using ASHRAE } \\
\text { guidelines was determined in the study. }\end{array}$ \\
\hline Chaudhary et al. & Acetanilide & Increase of efficiency by $32.3 \%$ \\
\hline
\end{tabular}

plant. This hybrid model utilizes direct solar radiation which is available in the desert like climate. It improved thermal cycle efficiency of the power plant. Fig. 11 shows the direct normal incidence versus efficiency plot for the integrated cycle.

\section{Efficiency Study Conducted \& Reasons}

At Lower flow rates lower thermal efficiencies of Using heat exchanger in absorber section led to high ptical efficiency of collector. operating time of plant by $61 \%$.

Aluminum oxide nano-fluid 5-10\% increase in collector efficiency 


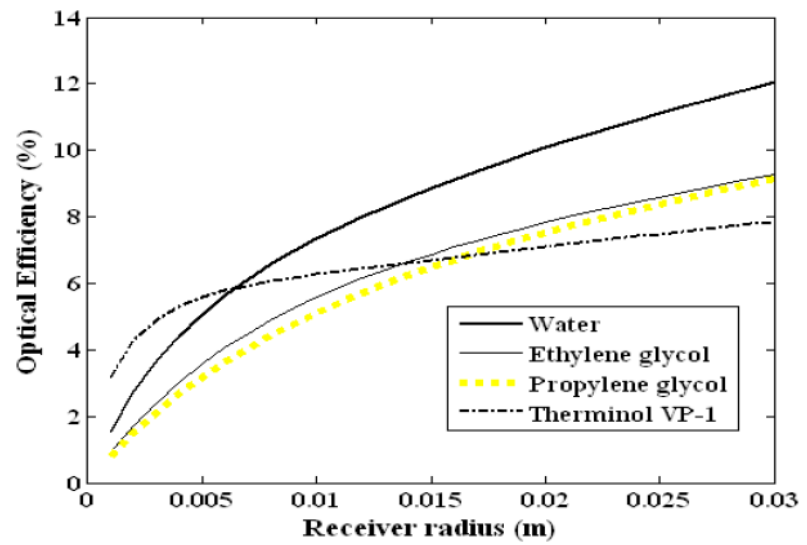

Fig. 10 Optical efficiency vs Receiver tube radius for different working fluids (Khullar et al. 2011)

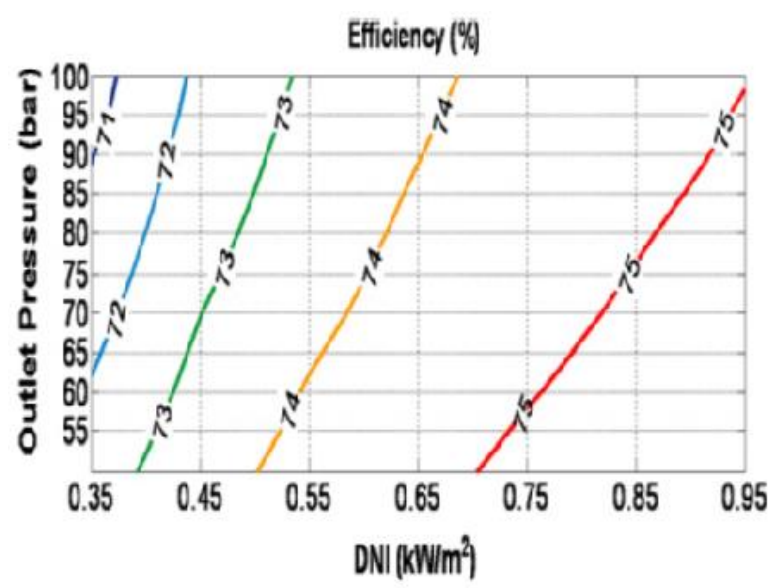

Fig. 11 Solar efficiency per collector loop as a function of the DNI vs and outlet solar field pressure (Montes et al. 2011)

The heat losses occurred at the receiver tube of the PTC is estimated. The arrangement of the absorber tube as shown in Fig.12 is investigated by Mohammed et al. The variations in the temperatures of the absorber tube are calculated in this study.

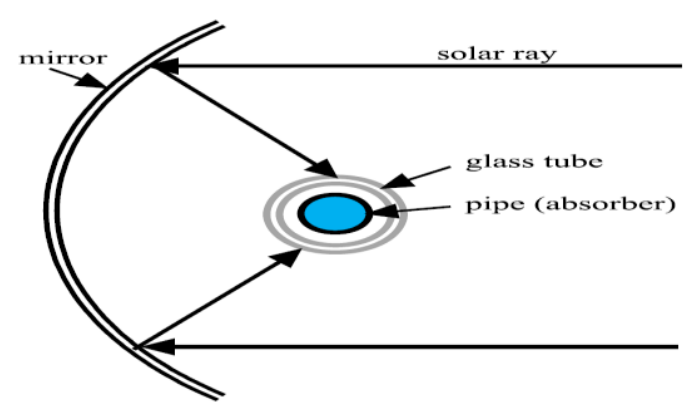

Fig. 12 Partially vaccumed absorber tube in a parabolic collector (Mohamadi et al. 2013)
A homogenizing reflector (HR) is introduced to improve the flux distribution homogeneity in a PTC It was observed by Wang et al. that circumferential distribution of the temperature of the receiver was homogenous after the introduction of the HR. Hachicha et al. developed a code based on Finite volume method to analyze the different segments of the receiver of PTC. By placing baffles into the receiver cavity of the solar PTC, Singh et al. observed that the performance of the solar collectors improved. Reddy et al. numerically studied the solar parabolic trough collector and the aspects of the collector and their impact on the collector performance are thoroughly analyzed. The angle of the collector its distance of space between collectors, the irradiance levels at the locations are considered for the analysis and the optimum sizing of the collector obtained. Al-Ansary et al. numerically investigated the performance of a halfinsulated receiver as against a conventional air-filled receiver. The arrangement of the study is shown as in Fig. 13. The results are very promising as they suggest that when compared to air filled annulus there is a reduction of $25 \%$ in heat losses when half annulus insulation is used. Cheng et al. used Finite Volume Method and Monte Carlo Ray-Trace method for numerical model development. Based on it, temperature distribution of the receiver is plotted which is shown in Fig 14. The property of high temperature fluids affects heat loss conditions of the receiver.

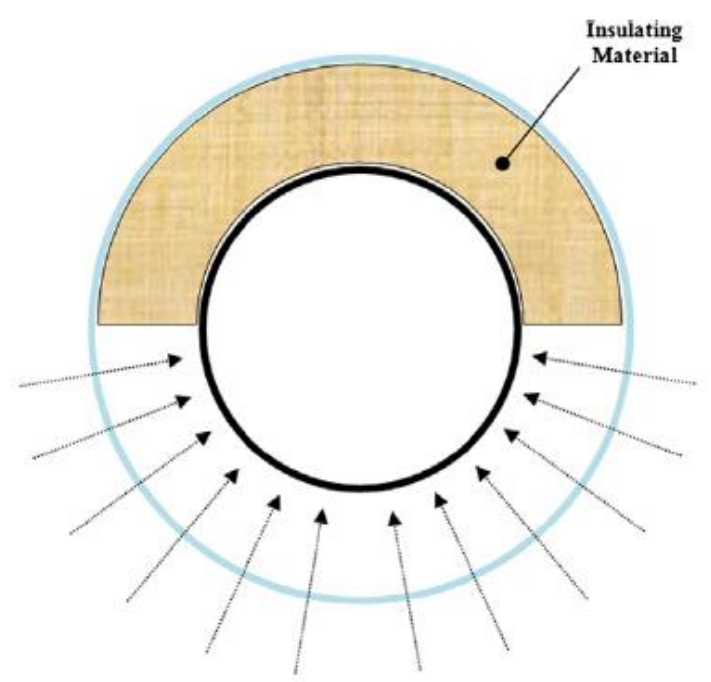

Fig. 13 Schematic of the proposed receiver having top half insulating material (Ansary et al. 2012) 


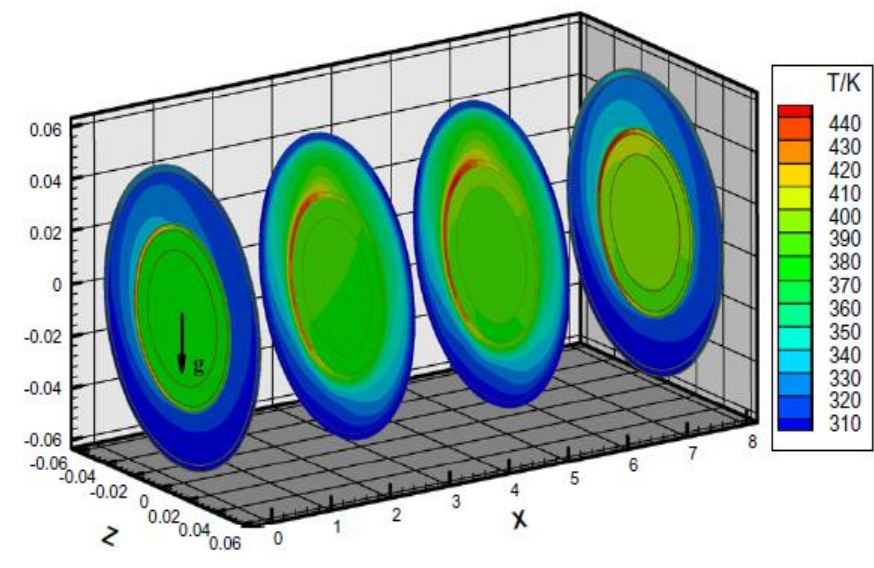

Fig. 14 Visible computational results of temperature distributions in the receiver (Cheng et al. 2012)

Penga et al. deployed the integrated solar parabolic trough collector with the fossil fired thermal power plant. The rotatable type two axes collector concentrates the solar irradiance and helps in the generation of elevated temperature of the preheated condensate thereby improving the hybrid power plants overall efficiency by about $4 \%$. The seasonal patterns are seen in Fig. 15.
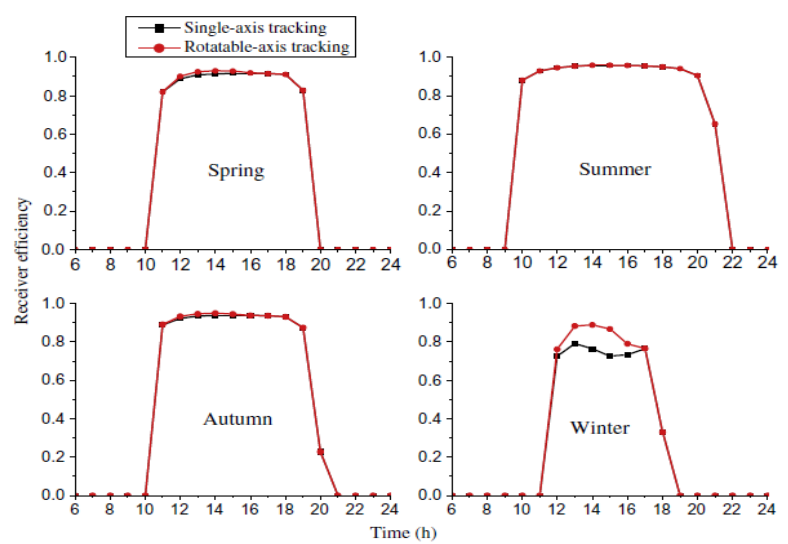

Fig. 15 Improvements in collector efficiency under different seasonal (Penga et al. 2013)

Coccia et al. developed and tested mathematical model and validated the results on a prototype model. The model envisages calculation of thermal efficiency and optical efficiency of the parabolic trough collector. The details of Numerical studies as reported by various investigators are presented in Table 2.

\section{SIMULATION STUDIES ON PARABOLIC SOLAR COLLECTORS}

Ibarra et al. conducted simulation on a parabolic trough collector-based power plant. The model is compared with performance of a solar plant in a desert condition. Actual values of power output obtained in the field were compared with model values for the same solar insolation rates and ambient temperatures. An acceptable error of $10 \%$ due to over estimation of solar field production was recorded.

Murtaza et al. used ANSYS software for simulating outlet temperature of absorber tube under varying flow conditions. At a flow rates of 0.4 LPM to 1.2LPM, the outlet temperature obtained were in the range of $93^{\circ} \mathrm{C}$ to $103^{\circ} \mathrm{C}$.Using ANSYS the tube displacement of $0.2 \mathrm{~mm}$, Von Mises stress within the strength limits of the material were obtained and small values of thermal strain were inferred using ANSYS software. Riffelmann et al. conducted simulation studies to measure the solar flux in the focal axis of the parabolic collector. They used a Parabolic Trough Flux Scanner (PARASCAN) instrument to quantify the solar flux in the concentrated region. A camera target method (CTM) is used to track the paths of the reflected rays and detect any errors in the reflective surface. Kalogirou et al. employed a transient simulation system TRNSYS with a PTC water heating system and the tracking in the E-W and N-S has been conducted and compared. Benefit analysis is performed for the use of this scheme. Odeh et al. studied with the help of a synthetic oil heat transfer fluid to simulate the losses of the collector.

Risi et al. investigated on an innovative solar Transparent Parabolic Trough Collector (TPTC) with gas based nanofluid as the working fluid. Due to gaseous medium and an increase in the heat exchange surface, the feature helps in additional solar radiation absorption when compared to nanoparticles dispersed in the base liquid. Odeh et al. employed a transient condition for simulation model wherein the size of the thermal storage tank in relation to the receiver collector area is deduced. For transient response to temperature changes it is found that the storage tank should be at least 14.5 liters capacity per 1 square meter of the collector area. Gonzalez et al. used methanol and combination of an activated carbon in an absorption chiller device and coupled to PTC. The chiller performance is checked at varying conditions. 


\begin{tabular}{|c|c|c|}
\hline Investigators reference & $\begin{array}{l}\text { Heat Transfer Fluid used } \\
\text { in the collector }\end{array}$ & Findings \\
\hline Hachicha et al. & water & $\begin{array}{l}\text { Numerical study predicted solar flux along receiver } \\
\text { tube to high accuracies (error band }<10 \% \text { ) }\end{array}$ \\
\hline Ghasemi et al. & $\begin{array}{ll}\text { Copper } & \text { oxide-water } \\
\text { nano-fluid }\end{array}$ & Thermal efficiency of the collector improved \\
\hline Khullar et al. & $\begin{array}{l}\text { Aluminum nano-particles, } \\
\text { Ethylene glycol, } \\
\text { Propylene glycol, } \\
\text { therminol VP-1 }\end{array}$ & Optical efficiency compared for four nano-fluids \\
\hline Montes et al. & water & $\begin{array}{l}\text { High pressure steam is obtained and marginally } \\
\text { improves the gas turbine efficiency. }\end{array}$ \\
\hline Mohamad et al. & water & $\begin{array}{l}\text { effect of the collector length on the heat losses from } \\
\text { the absorber is analyzed }\end{array}$ \\
\hline Kun et al. & water & $\begin{array}{l}\text { Homogenizing reflector reduced the variability of } \\
\text { circumferential temperature }\end{array}$ \\
\hline Hachicha et al. & water & Different segments of receiver studied \\
\hline Singh et al. & water & $\begin{array}{l}\text { baffles into the receiver cavity improved the } \\
\text { performance }\end{array}$ \\
\hline Reddy et al. & water & $\begin{array}{l}\text { Detailed numerical analysis of aspects of trough } \\
\text { collector are made. }\end{array}$ \\
\hline Al-Ansary et al. & Air-filled annulus & $\begin{array}{l}\text { Reduction of heat loss by } 25 \% \text { when half annulus } \\
\text { insulation is used. }\end{array}$ \\
\hline Cheng et al. & $\begin{array}{l}\text { Syltherm } 800 \text {, therminol, } \\
\text { VP nitrate salt, } \\
\text { Hitec XL }\end{array}$ & Properties of heat transfer fluid affects the heat losses \\
\hline Penga et al. & water & $\begin{array}{l}\text { Improved the hybrid power plants overall efficiency by } \\
\text { about } 4 \% \text {. }\end{array}$ \\
\hline Coccia et al. & water & $\begin{array}{l}\text { Mathematical model predicted thermal \& optical } \\
\text { efficiency of the prototype. }\end{array}$ \\
\hline
\end{tabular}

Table 2 Results of Numerical Studies on Parabolic Solar Collectors

He et al. investigated by simulation on a heat tube by employing Monte Carlo Ray Tracing technique. It is implied that the geometric concentration ratios are playing a role in the heat flux distribution. Mazloumi et al. simulated on a lithium bromide absorption cycle in which a PTC is used along with an insulated storage tank. By simulation it is calculated that a collector area of $57.6 \mathrm{~m}^{2}$ was required for supplying the cooling loads during the summer months. Huang et al. simulated on a PTC receiver fitted with a vacuum receiver tube.
Hedayatizadeh et al. simulated on a combined model consisting of a thermal model with a compound parabolic collector CPC and an electrical model consisting of a photovoltaic panel. Computational simulations are carried out for various conditions of climate. The results of simulation are in good agreement with their experimental measurements as can be seen in Fig. 16. 


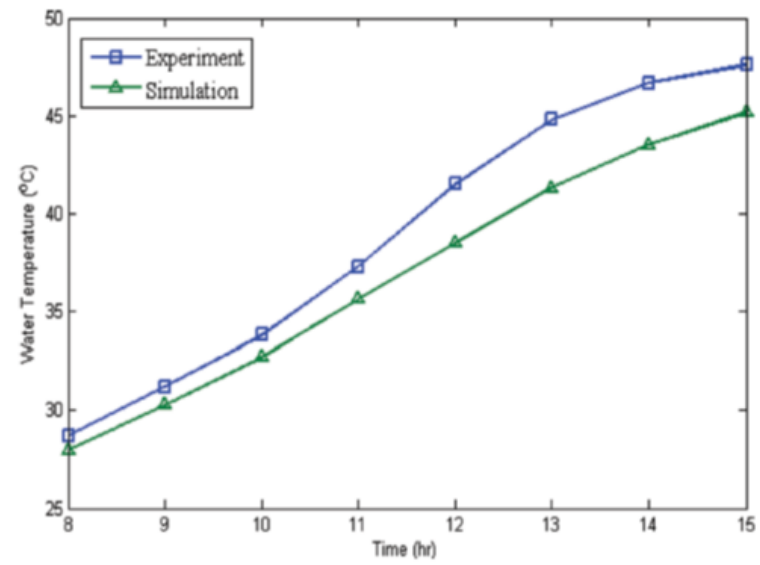

Fig. 16 Hourly variation of water temperature experimental vs Theoretical (Mazloumi et al. 2008)

The details of simulation studies have been reported in the Table 3.

\section{CONCLUSION}

The presented overview sought to publish an account of rich findings in the study of Parabolic Trough Solar collectors. The method of experimentation conducted by several researchers for studying the various parameters linked to parabolic troughs collector has been analyzed exhaustively. Researchers have employed numerical methods and studied the efficiencies of the parabolic collectors under different conditions. As a parallel process, the researchers also focused on subjecting the collector to simulation studies progressively improving the aspects of the collector surface for better absorptivity and emissivity. The research findings point to the evidence that good agreements of results across all the three types of studies are obtained. Use of nanofluids in liquid as well as gaseous phases in reflective and transparent collectors holds promise for further research in the field of improvements of parabolic solar trough type receivers.

\begin{tabular}{|l|l|}
\hline Investigators reference & Findings \\
\hline Ibarra et al. & $\begin{array}{l}\text { Simulation model predicted actual power output from a desert-based power plant } \\
\text { close to 90\% accuracy. }\end{array}$ \\
\hline Murtaza et al. & $\begin{array}{l}\text { ANSYS simulation model predicted outlet temperature of absorber tube at varying flow } \\
\text { rates. }\end{array}$ \\
\hline Riffelmann et al. & A camera target method (CTM) is used \\
\hline Kalogirou et al. & Transient simulation system TRNSYS is used \\
\hline S.D. Odeh et al. & Synthetic oil used to simulate the losses of the collector \\
\hline A de Risi et al. & Transparent Parabolic Trough Collector (TPTC) used \\
\hline Odeh et al.. & Employed a transient condition for simulation model \\
\hline Gonzalez et al. & Simulation of performance was conducted on an integrated chiller coupled to PTC. \\
\hline Ya-Ling He et al. & $\begin{array}{l}\text { MCRT technique suggested heat flux distribution to be dependent on geometric } \\
\text { concentration ratio of PTC. }\end{array}$ \\
\hline Mazloumi et al. & $\begin{array}{l}\text { Simulation of a thermal storage integrated PTC was employed for calculating the } \\
\text { collector area requirement. }\end{array}$ \\
\hline Huang et al. & $\begin{array}{l}\text { Evacuated vaccum tube integrated PTC was simulated to note heat loss distribution in } \\
\text { PTC. }\end{array}$ \\
\hline Hedayatizadeh et al. & $\begin{array}{l}\text { Solar thermal-SPV hybrid model } \\
\text { was simulated at varying conditions of solar radiation for comparison with } \\
\text { experimental results. }\end{array}$ \\
\hline
\end{tabular}

Table 3: Results of Simulation Studies on Parabolic Solar Collectors 


\section{ACKNOWLEDGEMENT}

The work reported in this review paper was partially presented at the International Conference on Manufacturing Excellence, held at Amity University, Uttar Pradesh, India.

\section{ABBREVIATIONS USED}

ASHRAE: American Society of Heating Refrigeration and Air-conditioning Engineers

CCGT: Combined Cycle Gas Turbine

CFD: Computational Fluid Dynamics

COP: Coefficient of Performance

CPC: Compound Parabolic Concentrator

CTM: Camera Target Method

DSG: Direct Steam Generation

FPC: Fresnel Prism Collectors

FVM: Finite Volume Method

GC: Geometric concentration ratio

HCE: Heat Collector Element

HR: Hmogenizing Reflector

HTF: Heat Transfer Fluid

ISCC: Integrated Solar Combined Cycle

MCRT: Monte Carlo Ray-Trace

NCPS: Nanofluid based Parabolic solar collector

PARASCAN: Parabolic Trough Scanner

PCM: Phase Change Material

PTC: Parabolic Trough Collector

PTSC: Parabolic Trough Solar Collector

SEGS: Steam based electric generation system

SODIS: Solar water Disinfectant

SPLFR: Semi Parabolic Linear Fresnel Reactor

TPTC: Transparent Parabolic Trough Collector

TRNSYS: Transient System Simulation Tool

\section{REFERENCES}

Abu-Hamdeh, H.N., Alnefaie, A.K., Almitani, H.K. 2013, 'Design and performance characteristics of solar adsorption refrigeration system using parabolic trough collector:Experimental and statistical optimization technique', Energy Conversion and Management, vol. 74, pp. 162 - 170.

Al-Ansary, H. and Zeitoun, O. 2011, 'Numerical study of conduction and convection heat losses from ahalf-insulated air-filled annulus of the receiver of a parabolic trough collector', Solar Energy, vol. 85, pp. 3036 - 3045.

Bellos, E., Tzivanidis, C., Antonopoulos, A.K. 2017, 'A detailed working fluid investigation for solar parabolic trough collectors Applied Thermal Engineering', DOI: 1016/j.applthermaleng.2016.11.201.

Calisea, F., Palomboa, A., Vanolib, L. 2012, 'Finite-volume model of a parabolic trough photovoltaic/thermal collector: Energetic and exergetic analyses', Energy, vol. 46, pp. $283-$ 294.

Chaudhary, A., Kumar, A., Yadav, A. 2013, 'Experimental investigation of a solar cooker based on parabolic dish collector with phase change thermal storage unit in Indian climatic conditions', Journal of Renewable and Sustainable Energy, vol. 5, 023107

Cheng, Z.D., He, Y.L., Cui, F.Q., Xu, R.J., Tao, Y.B. 2012, 'Numerical simulation of a parabolic trough solar collector with non-uniform solar flux conditions by coupling FVM and MCRT method', Solar Energy, vol. 86, pp. $1770-1784$.

Coccia, G., 2012, 'Mathematical modelling of a prototype of a parabolic trough solar collector', Journal of Renewable and sustainable energy, vol. 4, pp. 023110.

Eames, C. and Norton, B. 1995, 'Thermal and Optical consequences of the introduction of baffles into compound parabolic concentrating solar energy collector cavities', Solar Energy, vol. 55, no. 2, pp. $139-150$.

Fernandez, P., Blanco, J., Sichel, C., Malato, S. 2005, 'Water disinfection by solar photocatalysis using compound parabolic collectors', Catalysis Today, vol. 101, pp. $345-352$.

Ghasemi, S.E., Mehdizadeh, GHR., Ahangar. 2014, 'Numerical analysis of performance of solar parabolic trough collector with Cu-Water nanofluid', International Journal of Nano dimension, vol. 5, no. 3, pp. $233-240$.

Gonzalez, I.M., Rodriguez, R.L., Lucio, H.J. 2009, 'Evaluation of thermal parameters and simulation of a solar-powered, solidsorption chiller with a CPC collector', Renewable Energy, vol. 34, no. 3, pp. $570-577$.

Hachicha, A.A., Rodriguez, I., Capdevila, R., Oliva, A., 2013,' 'Heat transfer analysis and numerical simulation of a parabolic trough solar collector', Applied Energy, vol. 111, pp. 581 - 592. Hachicha, A.A. 2016, 'Numerical simulation of a Parabolic Trough Solar Collector for Hot Water and Steam Generation', AIP Conference Proceedings, vol. 1734, 070013.

He, Y.L., Xiao, J., Cheng, Z.D., Tao, Y.B. 2011, 'AMCRT and FVM coupled simulation method for energy conversion process in parabolic trough solar collector', Renewable Energy, vol. 36, no. 3, pp. $976-985$.

Hedayatizadeh, M., Ajabshirchi, Y., Sarhaddi, F., Safavinejad, A., Farahat, S., Chaji, H. 2013, 'Thermal and Electrical Assessment of an integrated solar photo voltaic thermal water collector equipped with a compound parabolic collector', International Journal of Green Energy,vol. 10, pp. 494 - 522.

Huang, W., Hub, P., Chen, Z. 2012, 'Performance simulation of a parabolic trough solar collector', Solar Energy, vol. 86, pp. $746-755$.

Kasaeian, A.B.S. and Kowsary, F. 2014, 'Heat transfer enhancement in parabolic trough collector tube using Al203/synthetic,oil nano fluid', Renewable and Sustainable Energy Reviews, vol. 33, pp. $636-644$.

Kasaeian, A., Davirana, S., Azarian, D.R., Rashidi, A. 2015, 
'Performance evaluation using nanofluid and capability study of a solar parabolic trough collector', Energy conversion and management, vol. 89, pp. $368-375$.

Kalogirou, A.S. 2002, 'Parabolic trough collectors for industrial process heat in Cyprus', Energy, vol. 27, pp. 813-830.

Khullar, V., and Tyagi, H. 2011, 'Enhancing Optical Efficiency of a Linear Parabolic Solar Collector through Nanofluids', AIP conference proceedings, vol. 1391, no. 353.

Khullar, V., Tyagi, H., Phelan, E.P, Otanicar, P.T, Singh, H., Taylor, A.R. 2012, 'Solar energy harvesting by using nanofluids based concentrating solar collector', Conference on Micro/Nanoscale Heat and Mass Transfer. ASME, pp. 259-267. Kordmahaleh, AA., Naghashzadegan, M., Javaherdeh, K., Khoshgoftar, M. 2017, 'Design of a 25MWe Solar Thermal Power Plant in Iran with Using Parabolic Trough Collectors and a Two-Tank Molten Salt Storage System', International Journal of Photoenergy. Hindawi, no. 11, Article ID 4210184.

Mazloumi, M., Naghashzadegan, M., Javaherdeh, K. 2008, 'Simulation of solar lithium bromide water absorption cooling system with parabolic trough collector', Energy Conversion and Management, vol. 49, no. 10, pp. $2820-2832$.

Mohamadi, A., Orfi, J., ansary, Al, H. 2013, 'Heat losses from parabolic trough solar collectors', Journal of Energy Research, vol. 38, no. 1, pp. $20-28$

Montes, MJ., Rovir, A., Munoz, M., Martinez-Val, JM., 2011, 'Performance analysis of an Integrated Solar Combined Cycle using Direct Steam Generation in parabolic trough collectors', Applied Energy, vol. 88, no. 9, pp. $3228-3238$.

Murtuza, A.S., Byregowda, H.V., Ali, M.M.H., Imran, M. 2017, 'Experimental and simulation studies of parabolic trough collector design for obtaining solar energy', Resource-Efficient Technologies, vol. 3, pp. $414-421$.

Nalwanga, R., Quilty, B., Muyanja, C., Fernandez-Iban, P. 2014, 'Evaluation of solar disinfection of Eschereschia coli bacterium under Sub-Saharan field conditions using a $25 \mathrm{~L}$ borosilicate glass batch reactor fitted with a compound parabolic collector', Solar Energy volume, vol. 100, pp. 195 - 202.

Odeh, S.D., Morrison, G.L., Behnia, M. 1998, 'Modelling of Parabolic Trough Direct Steam Generation Solar Collectors', Solar Energy, vol. 62, no. 6, pp. $395-406$.

Odeh, D.S. and Morrison, G.L. 2006, 'Optimization of parabolic trough solar collector system', International Journal of Energy Research, vol. 30, no. 4, pp. $256-271$.

Ouagued, M., Khellaf, A., Loukar, L. 2013, 'Estimation of the temperature, Heat gain and Heat loss by solar parabolic trough collector under Algerian climate using different thermal oils', Energy Conversion and Management, vol. 75, pp. $191-201$.

Pecha, A., and Soberanis, MA Escalante. 2012, 'Efficiency curves analysis of a parabolic trough solar collector in the Yucatan Peninsula', Journal of Renewable and Sustainable Energy 4, 021203.

Penga, S., Honga, H., Jina, H., Zhang, Z. 2013, 'A New rotatableaxis tracking solar parabolic-trough collector for solar-hybrid coal-red power plants', Solar Energy, vol. 98, pp. $1770-1784$. Riffelmann, K.J. 2006, 'Performance enhancement of parabolic trough collectors by solar flux measurement in the focal region', Solar Energy, vol. 80, no. 10, pp. 1303 - 1313.

Reddy, K.S. and Kumar, R.K. 2012, 'Solar collector field design and viability analysis of stand-alone parabolic trough power plants for Indian conditions', Energy for Sustainable Development, vol. 16, pp. $456-470$.

Risi, d.A., Milanese, M., Laforgia, D. 2013,' 'Modelling and optimization of transparent parabolic trough collector based on gas-phase nanofluids', Renewable Energy, vol. 58, pp. 134 139.

Singh, H. and Eames, PC. 2011, 'A Review of natural convective heat transfer correlations in rectangular cross-section cavities and their potential applications to compound parabolic concentrating (CPC) solar collector cavities', Applied Thermal Engineering, vol. 31, pp. $2186-2196$.

Tayade, G., Mayur., Thombre, E. R., Dutt, S. 2014, 'Performance Evaluation of Solar Parabolic Trough', International Journal of Nano Dimension, vol. 5, no. 3, pp. 233 $-240$.

Valenzuela, L., Hernandez-Lobon, D., Zarzaa, E. 2012, 'Sensitivity analysis of saturated steam production in parabolic trough collectors', Energy Procedia, vol. 30, pp. 765 - 774.

Wang, K., He, Y.,Cheng, Z. 2014, 'A design method and numerical study for a new type parabolic trough collector with uniform solar flux distribution', Science China Technological Sciences, vol. 57, pp. $531-540$.

Wang, R., Qu, W., Sun, J., Hong, Hu. 2017, 'An on-site test method for optical efficiency of large-size parabolic trough collectors', Energy Procedia, vol. 105, pp. $486-491$. 